\title{
The effects of $\beta$-glucan isolated from Pleurotus ostreatus on the development of arthritis and methotrexate treatment in rats with adjuvant arthritis
}

\author{
Wpływ $\beta$-glukanu izolowanego z Pleurotus ostreatus na rozwój zapalenia stawów \\ oraz leczenie metotreksatem u szczurów z adiuwantowym zapaleniem stawów
}

\author{
Jozef Rovenský1, Mária Stančíková1, Karol Švík ${ }^{1}$, Katarína Bauerová2, Jana Jurčovičováa \\ ${ }^{1}$ National Institute of Rheumatic Diseases, Piešt’any \\ 2Institute of Experimental Pharmacology and Toxicology at SAS, Bratislava \\ 3Institute of Experimental Endocrinology at SAS, Bratislava \\ ${ }^{1}$ Narodowy Instytut Chorób Reumatycznych, Pieszczany \\ 2Instytut Eksperymentalnej Farmakologii i Toksykologii przy SAS, Bratysława \\ 3Instytut Eksperymentalnej Endokrynologii przy SAS, Bratysława
}

Key words: $\beta$-glucan, methotrexate, adjuvant arthritis.

Słowa kluczowe: $\beta$-glukan, metotreksat, adiuwantowe zapalenie stawów.

\section{Summary}

Aim of the study: The purpose of this study was to evaluate the effect of $\beta$-(1,3/1,6)-D-glucan isolated from mushroom Pleurotus ostreatus ( $\beta$-glucan-PO) on the preventive treatment and therapy of adjuvant arthritis (AA) and methotrexate (MTX) treatment in rats.

Material and methods: Groups of rats with AA were preventively treated with methotrexate ( $1 \mathrm{mg} / \mathrm{kg} /$ week), $\beta$-glucan-PO $(1 \mathrm{mg} / \mathrm{kg}$ every second day) or their combination for a period of 28 days from adjuvant application. Methotrexate and $\beta$-glucan-PO ( $15 \mathrm{mg} / \mathrm{kg}$ every day) were also applied therapeutically from day 13 to day 35 after immunization. Body mass, hind paw swelling, arthrogram scores, and the level of serum albumin were measured as markers of inflammation and arthritis.

Results: Preventive treatment with a low dose of MTX significantly inhibited the markers of both inflammation and arthritis. Methotrexate and its combination with $\beta$-glucan-PO significantly increased the body mass of arthritic rats. $\beta$-glucan-PO administered alone had no effect on body mass but significantly decreased both the hind paw swelling and arthritic score. In combination with MTX, $\beta$-glucanPO markedly potentiated the beneficial effects of MTX, which resulted in a more significant reduction of hind paw swelling and arthritic scores. The concentration of albumin in the serum of arthritic controls was significantly lower than in the healthy controls. Both MTX alone and the combination treatment with MTX $+\beta$-glu-

\section{Streszczenie}

Cel pracy: Celem badania była ocena wpływu $\beta-(1,3 / 1,6)-D-$ -glukanu izolowanego z grzyba Pleurotus ostreatus ( $\beta$-glukan-PO) na postępowanie profilaktyczne oraz leczenie adiuwantowego zapalenia stawów (adjuvant arthritis - AA), a także na leczenie metotreksatem (MTX) u szczurów.

Materiał i metody: W grupie szczurów z AA profilaktycznie podawano MTX (1 mg/kg m.c. na tydzień), $\beta$-glukan-PO (1 mg/kg m.c. co drugi dzień) lub ich kombinację przez 28 dni od aplikacji adiuwantu. Metotreksat i $\beta$-glukan-PO (15 mg/kg m.c. codziennie) stosowano także terapeutycznie od 13 . do 35 . dnia po immunizacji. Jako markery stanu zapalnego oraz zapalenia stawów oceniano masę ciała, obrzęk tylnej łapy, wynik oceny artrogramu oraz stężenie albumin w surowicy. Wyniki: Profilaktyczne podawanie małej dawki MTX znamiennie hamowało markery zarówno stanu zapalnego, jak i zapalenia stawów. Metotreksat i jego kombinacja z $\beta$-glukanem-PO znamiennie zwiększała masę ciała u szczurów z zapaleniem stawów. $\beta$-glukan-PO podawany w monoterapii nie wptywał na masę ciała, ale znamiennie zmniejszał zarówno obrzęk tylnej łapy, jak i wynik oceny zapalenia stawów. W skojarzeniu z MTX, $\beta$-glukan-PO znacznie wzmacniał korzystne działanie MTX, co powodowało wyraźniejsze zmniejszenie obrzęku tylnej łapy oraz obniżenie wskaźników oceny zapalenia stawów. Stężenie albuminy w surowicy u szczurów w grupie kontrolnej z zapaleniem stawów było znamiennie mniejsze niż w grupie kontrolnej zdro-

Address for correspondence:

Prof. Jozef Rovenský, MD, DrSc, FRCP, National Institute of Rheumatic Diseases, Nábrežie I. Krasku 4, 92101 Piešt’any, tel. 0042133 7969111, fax 0042133 7721192, e-mail: rovensky.jozef @nurch.sk

Submitted: 12.06 .2013 
can-PO significantly inhibited the decrease of serum albumin. Therapeutically, MTX had no significant effect on the markers of inflammation and arthritis. $\beta$-glucan-PO alone in a high dose $(15 \mathrm{mg} / \mathrm{kg}$ body mass) inhibited hand paw swelling, arthrogram scores, and the decrease of serum albumin.

Conclusions: $\beta$-glucan-PO alone positively affected both the development and treatment of adjuvant arthritis in rats and increased the efficacy of basal treatment with MTX. In patients with rheumatoid arthritis this immunomodulator may prevent secondary infections and restore impaired immunological homeostasis.

$\beta$-glucans are long-chain polysaccharides containing D-glucose monomers linked by $\beta$-glycosidic bonds, with or without $\beta$-1,6-(D)-glucose smaller side chains. They belong to the group of polysaccharides present in the cell wall of bacteria, fungi, yeast, but also in cereals such as barley and oat [1]. Glucans differ not only in the molecule length and branching, but also in their tertiary structure based on their source. They are regarded as immune response modulators, non-specific stimulators of the immune system with several interactions with inherent and adaptive immunity of the host [2]. The induction of cellular responses by $\beta$-glucans is likely to involve their specific interaction with several cell surface receptors, such as complement receptor 3 , lactosylceramide, selected scavenger receptors, and dectin- 1 [3-5]. $\beta$-glucans increase host immune defense by activating the complement system, enhancing the phagocytic and proliferation activity of professional phagocytes - granulocytes, monocytes, macrophages, and dendritic cells. The use of $\beta$-glucans alone or as vaccine adjuvants for viral and bacterial antigens has been shown in animal models to increase resistance to a variety of bacterial, fungal, protozoan and viral infections [6-8]. $\beta$-glucans also show anticarcinogenic activity. Their use as adjuvants to cancer chemotherapy and radiotherapy demonstrated a positive role in the restoration of hematopoiesis following bone marrow injury [9-11].

$\beta$ - $(1,3 / 1,6)$-D-glucan is an insoluble polysaccharide isolated from the mushroom Pleurotus ostreatus. It is a safe and beneficial nutritional supplement with a strong system effect that is manifested in particular through the stimulation of specific immunity combined with antioxidant activity [11-13]. Recently, Smiderle et al. [14] described the anti-inflammatory and analgesic activity of $\beta-(1,3 / 1,6)$-Dglucan isolated from Pleurotus ostreatus on the acetic acidinduced writhing reaction in mice, a typical model for quantifying inflammatory pain. The authors suggested that the glucan had potent anti-inflammatory and analgesic activities, possibly due to the inhibition of pro-inflammatory wych osobników. Zarówno MTX w monoterapii, jak i leczenie skojarzone MTX + $\beta$-glukan-PO znamiennie hamowało zmniejszanie stężenia albuminy w surowicy. Pod względem terapeutycznym MTX nie wywierał istotnego wpływu na markery stanu zapalnego oraz zapalenia stawów. $\beta$-glukan-PO w dużej dawce (15 mg/kg m.c.) w monoterapii hamował obrzęk tylnej łapy, poprawiał wyniki oceny artrogramu oraz stężenie albuminy w surowicy.

Wnioski: $\beta$-glukan-PO w monoterapii działał korzystnie zarówno na rozwój, jak i leczenie AA stawów u szczurów oraz zwiększał skuteczność podstawowego leczenia za pomocą MTX. U pacjentów z reumatoidalnym zapaleniem stawów taki immunomodulator może zapobiegać wtórnym infekcjom i przywracać upośledzoną homeostazę immunologiczną.

cytokines. In our previous studies with application of $\beta$-(1,3/1,6)-D-glucan isolated from Pleurotus ostreatus to rats with adjuvant arthritis (AA) we observed decreased activities of pro-inflammatory cytokine TNF- $\alpha$ (tumor necrosis factor $\alpha$ ), IL-1 (interleukin 1) and IL- 6 in the serum of arthritic rats, decreased oxidative stress and suppressed inflammatory and arthritic signs in rats $[15,16]$. Protective antioxidant activity and anti-inflammatory activities of carboxylated (1-3)- $\beta$-D-glucan isolated from Saccharomyces cerevisiae were reported in adjuvant arthritis in Lewis rats [17].

Methotrexate is an antifolate that is widely used in the treatment of rheumatic disorders and malignant tumors. The efficacy of methotrexate is often limited by severe side effects, which also includes the development of oxidative stress. Sener et al. [18] showed that $\beta$-glucan can ameliorate the methotrexate-induced oxidative organ injury (liver or kidney) in rats via its antioxidant and immunostimulatory effects.

Our previous results showed the beneficial effects of $\beta$-(1,3/1,6)-D-glucan in an animal model of rheumatoid arthritis $[15,16]$. The aim of this study was to evaluate its effect on the development of arthritis and methotrexate treatment in rats with $A A$ in both the preventive and therapeutic regimen.

\section{Material and methods \\ Material}

Methotrexate $10 \mathrm{mg} / \mathrm{ml}$ solution for injection in sterile physiological saline was supplied by Medac Company, Hamburg, Germany. $\beta$-(1,3/1,6)-D-Glucan is an insoluble micronized pure compound isolated from Pleurotus ostreatus ( $\beta$-glucan-PO). $\beta$-(1,3/1,6)-D-glucan (Imunoglukán ${ }^{\circledR}$ ) was obtained from Pleuran s.r.o. company (Bratislava, Slovakia). Mycobacterium butyricum was purchased from Difco Laboratories Co. Ltd. (Detroit, MI, USA) and Freund's incomplete adjuvant from Sigma-Aldrich Chemie $\mathrm{GmbH}$ (Germany). 


\section{Animals}

Male Lewis rats (160-180 g) obtained from Charles River Wiga, Germany were maintained during the experiment in standard animal facilities that comply with the European Convention for the Protection of Vertebrate Animals Used for Experimental and Other Scientific Purposes. The animals were fed pelleted food (TOP DOVO, Dobrá Voda, Slovak Republic) and had free access to both food and water. The State Veterinary Committee of the Slovak Republic and the Ethics Committee for Control of Animals Experimentation at the National Institute of Rheumatic Diseases approved the experimental protocol and all procedures.

\section{Induction of arthritis}

The rats were injected with a $0.1 \mathrm{ml}$ suspension of heat killed Mycobacterium butyricum (12 mg/ml) in incomplete Freund's adjuvant intradermally at the base of the tail.

\section{Treatment}

Methotrexate and $\beta$-glucan-PO were administered preventively in corresponding doses from day 0 (the day of immunization) to day 28 of the study. Methotrexate was prepared by dilution with sterile saline to yield the desired concentration of $0.5 \mathrm{mg}$ in $0.1 \mathrm{ml}$ saline, and applied twice a week per os ( $1 \mathrm{mg} / \mathrm{kg}$ in total per week). $\beta$-glucanPO was administered orally as a suspension in saline every second day in a dose of $1 \mathrm{mg} / \mathrm{kg}$ body mass. Untreated animals received physiological saline in a similar manner. $\beta$-glucan-PO was administered therapeutically from day 13 of the study in a dose of $15 \mathrm{mg} / \mathrm{kg}$ every day (except Saturday and Sunday) up to day 35 of the experiment; the dose of MTX remained unchanged, but was only applied from day 13 of the experiment twice a week.

After a 14-day quarantine, the animals were divided into the following 8 groups of eight animals: group 1: healthy controls; group 2: untreated rats with AA (AA controls); group 3: AA rats preventively treated with $\beta$-glucan-PO; group 4: AA rats preventively treated with MTX; group 5: AA rats preventively treated with the combination of MTX + $+\beta$-glucan-PO; group 6: AA rats therapeutically treated from day 13 with MTX; group 7: AA rats therapeutically treated with $\beta$-glucan-PO from day 13 of the experiment; group 8: $A A$ rats therapeutically treated with the combination of MTX $+\beta$-glucan-PO from day 13 .

\section{Evaluated parameters}

Body mass of rats was measured at the beginning of the study and on days 1, 7, 14, 21, 28 and 35 of the experiment.

Hind paw swelling. The volume of the hind paw swelling was measured with an electronic water plethysmograph (UGO BASILE, Comerio-Varese, Italy) on days 14, 21, 28 and 35.
Arthrogram score. The severity of arthritis was quantified by scoring each paw from 0 to 5 , based on increasing levels of swelling and periarticular erythema. The sum of the scores for the limbs was calculated as the arthritic index, with a maximum possible score of 20 per rat. Arthrogram scores were evaluated on days 14, 21, 28 and 35.

Serum albumin levels were measured on days 14, 21, 28 and 35 in the rat serum by the spectrophotometric method, using the SYS 1 kit (BM/Hitachi, Boehringer Mannheim, Germany) on a Hitachi 911 automatic biochemical analyzer. Blood was taken from the retro-orbital sinus and was then processed into serum. The serum was stored at $-60^{\circ} \mathrm{C}$ until the albumin analysis.

Statistical analysis of the results. One-way analysis of variance (ANOVA) was used for statistical analysis of the results, and $p<0.05$ was considered as the significance limit for all comparisons.

\section{Results \\ Body weight}

In the first 7 days of the treatment, the increment in body weight was similar in all groups of rats (Table I). However, on day 14, the body mass of arthritic control rats and rats treated with $\beta$-glucan-PO alone was significantly lower than that of the healthy controls and arthritic rats preventively treated with MTX and with a combination of $\mathrm{MTX}+\beta$-glucan-PO. The loss of body mass in rats treated with the combination MTX $+\beta$-glucan-PO was similar to that in rats treated with MTX alone. The therapeutic application of MTX, $\beta$-glucan-PO, and the combination of $M T X+\beta$-glucan-PO from day 13 of the experiment did not influence the body mass of arthritic animals.

\section{Hind paw swelling}

Hind paw swelling reflects both arthritic and inflammatory changes occurring in AA rats. The volume of the swollen hind paws in arthritic rats was 1.5-1.7 times higher than in healthy controls (Table II). Statistically significant decreases of hind paw swelling were observed in arthritic rats preventively treated with MTX, $\beta$-glucan-PO, and the combination of MTX $+\beta$-glucan-PO on day 14,21 , and 28 of the experiment. The mean volumes of both paws are shown in Table II. $\beta$-glucan-PO alone, administered preventively, significantly reduced the hind paw swelling on day 21 and 28 after immunization. The combination treatment MTX $+\beta$-glucan-PO reduced this parameter statistically more significantly than MTX treatment alone (MTX vs. MTX $+\beta$-glucan-PO, $p<0.05)$.

Tested preparations behaved differently following application from day 13 after immunization when clinical signs of arthritis are already manifested, such as hind paw 
Table I. The effect of MTX, $\beta$-glucan-PO and their combination on the body mass of rats (g)

\begin{tabular}{|c|c|c|c|c|c|c|}
\hline Groups of rats & Day 1 & Day 7 & Day 14 & Day 21 & Day 28 & Day 35 \\
\hline Healthy controls & $167 \pm 6$ & $219 \pm 13$ & $224 \pm 13^{\star *}$ & $239 \pm 14^{\star \star \star}$ & $250 \pm 15^{\star \star \star}$ & $258 \pm 16^{* * *}$ \\
\hline AA controls & $170 \pm 8$ & $217 \pm 12$ & $186 \pm 11$ & $179 \pm 18$ & $199 \pm 13$ & $216 \pm 13$ \\
\hline \multicolumn{7}{|c|}{ AA rats treated from day 0 with: } \\
\hline$\beta$-glucan-PO & $171 \pm 6$ & $217 \pm 7$ & $193 \pm 10$ & $184 \pm 9$ & $212 \pm 12$ & \\
\hline MTX & $173 \pm 6$ & $227 \pm 7$ & $228 \pm 17^{\star \star *}$ & $236 \pm 14^{\star * \star}$ & $247 \pm 15^{\star * *}$ & \\
\hline MTX $+\beta$-glucan-PO & $171 \pm 6$ & $228 \pm 8$ & $231 \pm 18^{\star \star *}$ & $230 \pm 20^{\star \star *}$ & $244 \pm 24^{\star \star}$ & \\
\hline \multicolumn{7}{|c|}{ AA rats treated from day 13 with: } \\
\hline MTX & $172 \pm 8$ & $217 \pm 8$ & $195 \pm 13$ & $191 \pm 10$ & $204 \pm 8$ & $221 \pm 10$ \\
\hline$\beta$-glucan-PO & $173 \pm 6$ & $220 \pm 8$ & $193 \pm 15$ & $190 \pm 13$ & $201 \pm 16$ & $219 \pm 15$ \\
\hline MTX $+\beta$-glucan-PO & $171 \pm 8$ & $222 \pm 6$ & $191 \pm 13$ & $192 \pm 11$ & $202 \pm 15$ & $220 \pm 16$ \\
\hline
\end{tabular}

Data represent mean value and standard deviation (mean value $\pm S D$ ) for groups of 8 rats.

Significantly different from arthritic control rats: ${ }^{* *} p<0.01,{ }^{* * *} p<0.001$.

$A A$ - adjuvant arthritis, MTX - methotrexate.

Table II. The effect of MTX, $\beta$-glucan-PO and their combination on hind paw swelling in AA rats (ml)

\begin{tabular}{|c|c|c|c|c|}
\hline Groups of rats & Day 14 & Day 21 & Day 28 & Day 35 \\
\hline Healthy controls & $1.36 \pm 0.04^{\star * *}$ & $1.40 \pm 0.02^{\star * \star}$ & $1.41 \pm 0.05^{\star * *}$ & $1.43 \pm 0.04$ \\
\hline AA controls & $2.25 \pm 0.20$ & $2.51 \pm 0.18$ & $2.34 \pm 0.15$ & $2.08 \pm 0.22$ \\
\hline \multicolumn{5}{|c|}{ AA rats treated from day 0 with: } \\
\hline$\beta$-glucan-PO & $2.05 \pm 0.14$ & $2.31 \pm 0.09^{*}$ & $2.16 \pm 0.24^{*}$ & \\
\hline MTX & $1.85 \pm 0.23^{\star \star}$ & $2.16 \pm 0.22^{\star \star}$ & $2.04 \pm 0.30^{\star \star}$ & \\
\hline MTX $+\beta$-glucan-PO & $1.73 \pm 0.22^{\star * *}$ & $1.94 \pm 0.37^{\star * * \dagger}$ & $1.88 \pm 0.28^{\star * * \dagger}$ & \\
\hline \multicolumn{5}{|c|}{ AA rats treated from day 13 with: } \\
\hline MTX & $2.22 \pm 0.22$ & $2.42 \pm 0.20$ & $2.39 \pm 0.28$ & $1.98 \pm 0.22$ \\
\hline$\beta$-glucan-PO & $2.14 \pm 0.18$ & $2.09 \pm 0.23^{\star \star}$ & $1.97 \pm 0.22^{\star *}$ & $1.95 \pm 0.22$ \\
\hline MTX $+\beta$-glucan-PO & $2.24 \pm 0.21$ & $2.31 \pm 0.44$ & $2.28 \pm 0.47$ & $2.18 \pm 0.47$ \\
\hline
\end{tabular}

Data represent mean value and standard deviation (mean value $\pm S D$ ) for groups of 8 rats.

Significantly different from arthritic control rats: ${ }^{*} p<0.05,{ }^{* *} p<0.01,{ }^{* * *} p<0.001$.

Significantly different from arthritic rats treated with MTX: ${ }^{\dagger} p<0.05$

$A A$ - adjuvant arthritis, MTX - methotrexate.

swelling and periarticular erythema. The application of $\beta$-glucan-PO from day 13 after immunization in a dosage of $15 \mathrm{mg} / \mathrm{kg}$ of body mass also significantly reduced the hind paw swelling on day 21 and 28 of the experiment. Methotrexate alone and combined therapy with MTX $+\beta$ glucan-PO in a therapeutic regimen had no significant effect on hind paw swelling.

\section{Arthrogram score}

Arthrogram score similarly as hind paw swelling was significantly reduced by $\beta$-glucan-PO and MTX applied preventively. The combination treatment with $M T X+\beta$-glucan-PO was more efficient than MTX alone (Table III). $\beta$-glucan-PO administered in a therapeutic dose of $15 \mathrm{mg} / \mathrm{kg}$ significantly reduced the arthrogram score, similarly to hind 
Table III. The effect of MTX, $\beta$-glucan-PO and their combination on the arthrogram score in AA rats

\begin{tabular}{|c|c|c|c|c|}
\hline Groups of rats & Day 14 & Day 21 & Day 28 & Day 35 \\
\hline AA controls & $13.44 \pm 1.81$ & $16.22 \pm 1.99$ & $14.89 \pm 2.26$ & $12.84 \pm 2.14$ \\
\hline \multicolumn{5}{|c|}{ AA rats treated from day 0 with: } \\
\hline$\beta$-glucan-PO & $11.30 \pm 1.46$ & $14.25 \pm 0.53^{\star}$ & $12.14 \pm 2.10^{*}$ & \\
\hline MTX & $8.50 \pm 1.52^{\star \star}$ & $13.33 \pm 3.44^{\star *}$ & $11.00 \pm 2.53^{*}$ & \\
\hline MTX $+\beta$-glucan-PO & $8.25 \pm 2.25^{\star * *}$ & $10.88 \pm 2.85^{\text {** } \dagger}$ & $9.88 \pm 2.10^{\star * \star \dagger}$ & \\
\hline \multicolumn{5}{|c|}{ AA rats treated from day 13 with: } \\
\hline MTX & $14.10 \pm 1.54$ & $15.40 \pm 1.98$ & $13.92 \pm 2.18$ & $11.38 \pm 2.83$ \\
\hline$\beta$-glucan-PO & $13.80 \pm 2.10$ & $12.13 \pm 1.73^{\star \star *}$ & $11.63 \pm 2.39^{*}$ & $10.50 \pm 2.27^{\star}$ \\
\hline MTX $+\beta$-glucan-PO & $13.64 \pm 3.22$ & $14.38 \pm 4.72$ & $13.38 \pm 3.96$ & $12.13 \pm 3.64$ \\
\hline
\end{tabular}

Data represent mean value and standard deviation (mean value $\pm S D$ ) for groups of 8 rats.

Significantly different from arthritic control rats: ${ }^{*} p<0.05,{ }^{* *} p<0.01$, ${ }^{* * *} p<0.001$

Significantly different from arthritic rats treated with MTX: ${ }^{+} p<0.05$

$A A$ - adjuvant arthritis, MTX - methotrexate.

paw swelling. The therapeutic application of MTX and the combination of MTX $+\beta$-glucan-PO did not influence the arthrogram score.

\section{Serum albumin levels}

Serum albumin acts as a negative acute phase reactant in both rat and human arthritis. Lower levels of serum albumin correspond to higher levels of inflam- matory activity. The concentration of albumin in the serum of arthritic controls was significantly lower than in healthy controls (HC vs. AA rats, $p<0.001$ ). Both MTX and the combination treatment with MTX $+\beta$-glucanPO applied preventively significantly inhibited the decrease in serum albumin (Table IV). $\beta$-glucan-PO therapy reduced albumin decrease on day 21 . Combined therapy with MTX $+\beta$-glucan-PO was efficient on days 21 and

Table IV. The effect of MTX, $\beta$-glucan-PO and their combination on serum albumin concentrations $(\mathrm{g} / \mathrm{l})$ in AA rats

\begin{tabular}{|c|c|c|c|c|}
\hline Groups of rats & Day 14 & Day 21 & Day 28 & Day 35 \\
\hline Healthy controls & $42.00 \pm 2.70^{\star \star *}$ & $39.92 \pm 2.45^{\star * *}$ & $42.15 \pm 2.14^{\star \star \star}$ & $41.82 \pm 2.6^{* \star *}$ \\
\hline AA controls & $27.68 \pm 1.08$ & $30.91 \pm 2.10$ & $34.28 \pm 1.22$ & $36.42 \pm 2.14$ \\
\hline \multicolumn{5}{|c|}{ AA rats treated from day 0 with: } \\
\hline$\beta$-glucan-PO & $28.62 \pm 1.26$ & $30.66 \pm 1.71$ & $34.41 \pm 2.04$ & \\
\hline MTX & $32.01 \pm 3.36^{\star \star}$ & $35.33 \pm 1.79^{\star \star \star}$ & $38.03 \pm 2.19^{\star \star}$ & \\
\hline MTX $+\beta$-glucan-PO & $36.01 \pm 3.44^{\star * *}$ & $36.33 \pm 3.39^{\star \star \star}$ & $37.84 \pm 2.02^{\star \star}$ & \\
\hline \multicolumn{5}{|c|}{ AA rats treated from day 13 with: } \\
\hline MTX & $28.24 \pm 2.79$ & $31.42 \pm 2.14$ & $34.80 \pm 2.14$ & $37.22 \pm 2.45$ \\
\hline$\beta$-glucan-PO & $28.80 \pm 2.82$ & $36.21 \pm 4.67^{\star *}$ & $35.30 \pm 2.79$ & $36.24 \pm 2.10$ \\
\hline$M T X+\beta$-glucan-PO & $27.62 \pm 2.70$ & $35.21 \pm 4.24^{\star *}$ & $36.40 \pm 2.45^{\star}$ & $33.24 \pm 2.70^{*}$ \\
\hline
\end{tabular}

Data represent the mean value and standard deviation (mean value $\pm S D$ ) for groups of 8 rats. Significantly different from arthritic control rats: ${ }^{*} p<0.05,{ }^{* *} p<0.01,{ }^{* * *} p<0.001$.

$A A$ - adjuvant arthritis, MTX - methotrexate. 
28 of the experiment, but on day 35 after immunization the serum albumin was even lower in this group than in untreated arthritic animals, which may indicate that the inflammatory process was augmented following previous suppression.

\section{Discussion}

In the study we investigated the effect of $\beta$ - $(1,3 / 1,6)$ D-glucan isolated from Pleurotus ostreatus on inflammatory and arthritic parameters in rats with adjuvant arthritis and on the treatment with MTX. $\beta$-glucans, even in very high doses, are non-toxic and free of adverse reactions. The U.S. Food and Drug Administration classified $\beta$-glucan in the GRAS category (Generally Recognized As Safe), which means that there are no known dangerous interactions with other substances, adverse effects, or toxicity [19]. In rats, even doses of $2000 \mathrm{mg} / \mathrm{kg}$ of body mass did not lead to toxic effects. In our work, we are presenting the results of the preventive and therapeutic application of $\beta$-glucan and its effect on MTX treatment. Methotrexate, $\beta$-glucan, and their combination were preventively administered from the day of adjuvants application and from day 13 after immunization, when clinical signs of arthritis such as hind paw swelling and periarticular erythema are present. Doses of $\beta$-glucan in the preventive regimen were $1 \mathrm{mg} / \mathrm{kg}$ of body mass. Therapeutic doses of $\beta$-glucan were much higher, up to $15 \mathrm{mg} / \mathrm{kg}$ of body mass. These doses were applied alone and in combination with MTX.

The results of our investigation confirmed the previously reported effect of MTX treatment in rats with AA. Methotrexate at a dose of $1 \mathrm{mg} / \mathrm{kg} /$ week suppressed, but did not prevent, arthritis development [20, 21]. In our study, MTX applied preventively significantly suppressed hind paw swelling and reduced the arthrogram score. Therapeutically, its effect was not proved. $\beta$-glucan alone in the preventive regimen reduced both hind paw swelling and the arthrogram score on days 21 and 28 of the experiment. The remarkable finding was also that $\beta$-glucanPO potentiated the beneficial effect of MTX; it reduced both the hind paw swelling and arthrogram score more significantly compared to the rats treated with MTX alone. $\beta$-glucan-PO, in contrast to MTX, was capable of reducing both the hind paw swelling and arthrogram score even in the therapeutic regimen. In this connection, it is remarkable that such high doses of $\beta$-glucan-PO ( $15 \mathrm{mg} / \mathrm{kg}$ of body mass) as an immunostimulator were capable of suppressing the already started arthritic process.

Serum albumin acts as a negative acute-phase reactant in rat arthritis. Decreased levels of serum albumin reflect the changes in synthesis of this protein in the liver secondary to the activation of hepatic cells by inflammatory cytokines, mainly IL-1 [21]. Our results correlate with the observation that preventively applied MTX markedly prevents the albumin decrease in AA rats. The combination of MTX with $\beta$-glucan-PO had no additional effect compared to MTX alone. Therapeutically MTX had no effect on serum albumin. Interestingly, the combination of MTX with $\beta$-glucan-PO reduced albumin decrease also therapeutically, but at the end of the study on day 35 the serum albumin level decreased again, probably as a result of activation of suppressed inflammation.

Systemic administration of $\beta$-glucan to rats and mice has been demonstrated to protect against various infections by activation of macrophages and attenuation of proinflammatory cytokine release [13, 22-24]. Hetland et al. $[25,26]$ showed that $\beta$-glucan reduced growth of Mycobacterium tuberculosis in macrophage cultures and had a protective effect against Mycobacterium bovis BCG infection in BALB/c mice.

Some microbes, such as fungi and viruses, lead to generation and activation of autoimmune $T$ cells resulting in the development of a particular autoimmune disease in genetically susceptible individuals. $\beta$-(1,3/1,6)-D-glucan, an effective activator of the immune system, may also be beneficial in humans in preventing or eliminating bacterial infections which are known to induce reactive arthritis. The finding that $\beta$-glucan-PO, applied both preventively and therapeutically, has a beneficial effect on the clinical symptoms of arthritis, even at a high dose of $15 \mathrm{mg} / \mathrm{kg}$, may be interesting also in prevention and treatment of various infections in humans with rheumatoid arthritis.

Authors declare no conflict of interest.

This work was supported by APVV grant No. APVV-21055205 and Pleuran s.r.o., Bratislava, Slovakia.

\section{References}

1. Akramiené $D$, Kondratos A, Didžiapetriené J, Kévelaitis E. Effects of $\beta$-glucans on the immune system. Medicina (Kaunas) 2007; 43: 597-606.

2. Muta T. Molecular basis for invertebrate innate immune recognition of ( $1 \rightarrow 3$ )-beta-D-glucan as a pathogen-associated molecular pattern. Curr Pharm Des 2006; 12: 4155-4161.

3. Ross G, Cain J, Myones B, et al. Specificity of membrane complement receptor type 3 (CR3) for $\beta$-glucans. Complement 1987; 4: 61-74.

4. Brown GD, Tailor PR, Reid DM, et al. Dectin-1 is a major -glucan receptor on macrophages. J Exp Med 2002; 196: 407-412.

5. Brown GD, Gordon S. Immune recognition of fungal beta-glucans. Cell Microbiol 2005; 7: 471-479.

6. Ben-Ami R, Lewis RE, Kontoyiannis DP. Immunocompromised hosts: immunopharmacology of modern antifungals. Clin Infect Dis 2008; 47: 226-235.

7. Kernodle DS, Gates H, Kaiser AB. Prophylactic anti-infective activity of poly-[1-6]-beta-D-glucopyranosyl-[1-3]-beta-D-glucopryanose glucan in a Guinea pig model of staphylococcal wound infection. Antimicrob Agents Chemother 1998; 42: 545-549. 
8. Větvička V, Vashishta A, Saraswat-Ohri S, Vetvickova J. Immunological effects of yeast- and mushroom-derived beta-glucans. J Med Food 2008; 11: 615-622.

9. Weitberg AB. A phase I/II trial of beta- $(1,3) /(1,6)$ D-glucan in the treatment of patients with advanced malignancies receiving chemotherapy. J Exp Clin Cancer Res 2008; 27: 40.

10. Mantovani MS, Bellini MF, Angeli JP, et al. Beta-Glucans in promoting health: prevention against mutation and cancer. Mutat Res 2008; 658: 154-161.

11. Bobek P, Galbavy S. Effect of pleuran (beta-glucan from Pleurotus ostreatus) on the antioxidant status of the organism and on dimethylhydrazine-induced precancerous lesions in rat colon. $\mathrm{Br}$ J Biomed Sci 2001; 58: 164-168.

12. Bobek P, Galbavy S, Ozdin L. Effect of oyster mushroom (Pleurotus ostreatus) on pathological changes in dimethylhydrazineinduced rat colon cancer. Oncol Rep 1998; 5: 727-730.

13. Nosál'ová V, Bobek P, Černá S, et al. Effects of pleuran (beta-glucan isolated from Pleurotus ostreatus) on experimental colitis in rats. Physiol Res 2001; 50: 575-581.

14. Smiderle FR, Olsen LM, Carbonero ER, et al. Anti-inflammatory and analgesic properties in a rodent model of a $(1 \rightarrow 3),(1 \rightarrow 6)$-linked beta-glucan isolated from Pleurotus pulmonarius. Eur J Pharmacol 2008; 597: 86-91.

15. Bauerová K, Paulovičová E, Mihalová D, et al. Study of new ways of supplementary and combinatory therapy of rheumatoid arthritis with immunomodulators Glucomannan and Imunoglukán $\circledast$ in adjuvant arthritis. Toxicol Industrial Health 2009; 25: 329-335.

16. Stančíková M, Rovenský J, Švík K, et al. Effect of immunostimulators on adjuvant arthritis in rats (in Slovak). Rheumatologia 2008; 22: 9-11.

17. Kogan G, Staško A, Bauerová K, et al. Antioxidant properties of yeast $(1 \rightarrow 3)-\beta$-d-glucan studied by electron paramagnetic resonance spectroscopy and its activity in the adjuvant arthritis. Carbohydrate Polymers (Elsevier) 2005; 61: 18-28.

18. Sener G, Ek ioglu-Demiralp E, Cetiner M, et al. Beta-glucan ameliorates methotrexate-induced oxidative organ injury via its antioxidant and immunomodulatory effects. Eur J Pharmacol 2006; 542: 170-178.

19. Větvička V. Beta Glukan. Mystery of nature (in Czech). Centa, Brno, 2011.

20. Welles WL, Silkworth J, Oronsky AL, et al. Studies on the effect of low dose methotrexate in adjuvant arthritis. J Rheumatol 1985; 12: 904-906.

21. Connolly KM, Stecher VJ, Danis E, et al. Alteration of interleukin1 production and the acute phase response following medication of adjuvant arthritic rats with cyclosporin-A or methotrexate. Int J Immunopharmacol 1988; 10: 717-728.

22. Cleary JA, Kelly GE, Husband AJ. The effect of molecular weight and beta-1,6-linkages on priming of macrophage function in mice by (1,3)-beta-D glucan. Immunol Cell Biol 1999; 77: 395-403.

23. Onderdonk AB, Cisneros RL, Hinkson P, Ostroff G. Anti-infective effect of poly-beta-1-6-glucotriosyl-beta1-3-glucopyranose glucan in vivo. Infect Immun 1992; 60: 1642-1647.

24. Bedirli A, Kerem M, Pasaoglu $\mathrm{H}$, et al. Beta-glucan attenuates inflammatory cytokine release and prevents acute lung injury in an experimental model of sepsis. Shock 2007; 27: 397-401.
25. Hetland G, Lovik M, Wiker HG. Protective effect of beta-glucan against mycobacterium bovis, BCG infection in BALB/c mice. Scand J Immunol 1998; 47: 548-553.

26. Hetland G, Sandven P. Beta-1,3-glucan reduces growth of Mycobacterium tuberculosis in macrophage cultures. FEMS Immunol Med Microbiol 2002; 33: 41-45. 